http://dx.doi.org/10.7494/drill.2016.33.4.699

\author{
Dagmara Zeljaś*
}

\title{
HOW TO LOCALIZE AN UNDERGROUND GAS STORAGE (UGS) IN A SALT STRUCTURE OF THE FORE-SUDETIC MONOCLINE IN LIGHT OF ITS GEOMECHANICAL PROPERTIES**
}

\section{INTRODUCTION}

Each country should provide energy safety, which depends on various factors, e.g. geographic location, accessibility to home energy sources and import of energy carriers, preferably diversified. Another important issue which increases energy safety is the stored reserves. The more of these conditions are satisfied, the more stable is the economy and resistant to fluctuations on the energy market, unexpected economic crises, turmoil in the stock market and the seasonal character of energy demand. The world's practice in the underground storing of oil and liquid hydrocarbons shows that underground caverns leached out in salt formations are most advantageous for storing purposes. The experience of countries specializing in underground gas storages performed in salt structures dates back to the middle of the $20^{\text {th }}$ century. USA, Canada, and also many countries neighboring with Poland have already invested in their energy safety and developed strategic oil and natural gas reserves in underground storages [10]. The economic development of a country means higher gas consumption. The demand for this product constantly increases; in line with the current trends and the increasing ecological consciousness of the energy market participants, solid fuels consumption should be limited.

Natural gas consumption in Poland keeps on growing. In 2014 gas consumption totaled to about 15 billion $\mathrm{m}^{3}$. According to economic predictions this value may increase by $25 \%$ in the year 2050. Over 70\% of Poland's demand for gas is covered from import, the rest comes from home resources. Presently, Poland's annual production has been assessed to about 4.7 billion $\mathrm{m}^{3} .80 \%$ of import gas comes from the east and its deliveries are regulated by a long-term contract with the Russian Federation. Poland also imports gas from Germany (about 15\%), the Czech Republic (about 4.8\%) and Norway (0.2\%) [2]. This gas-supply structure strongly relies on one source and in a crisis situation the life of the country may

* AGH University of Science and Technology, Faculty of Drilling, Oil and Gas, Krakow, Poland

** Work realized within statutory research program of Faculty of Drilling, Oil and Gas, No. 11.11.190.565 
be paralyzed. Therefore Poland has undertaken measures to reverse this tendency implementing Poland's energy strategies and adjusting them to the respective EU Committee directives.

Poland invests in hydrocarbon prospecting to increase home production. Building an LNG terminal was a strategic investment which shall guarantee the energy safety to the country. In the future gas deliveries from the east should be reduced to about $30 \%$, and new distribution sources/media found. A few years ago Poland and Qatar signed a contract on gas deliveries, which are received in a new LNG terminal in Świnoujście.

Poland tends to develop its own gas transport, distribution and storage infrastructure by building new objects and modernizing the existing ones. The geographic localization has a big influence on the structure of gas consumption. Poland is located in Northeast Europe. The moderate climate results in uneven energy consumption over the year, with the growing trend between November and March, mainly in the communal and household sector. The consumption in the industrial sector is more stable. The development of transmission and distribution networks will allow for importing gas from the west and from the south. The development of the storage capacity shall smooth out the seasonal oscillations in the demand for this energy carrier.

Poland creates a Gas Hub to develop wholesale gas market and become a significant subject on the European gas market. There have been undertaken measures to lower the wholesale gas price, allow new subjects to the Polish gas market, increase the efficiency of use of interconnection points and LNG terminal in Świnoujście [11].

\section{POLISH UGS \\ IN THE CONTEXT OF RESPECTIVE FORMAL-LEGAL REGULATIONS AND ENERGY SAFETY OF THE COUNTRY}

At present Poland has nine underground gas storages of total capacity 2.98 billion $\mathrm{m}^{3}$ (Tab. 1). Two of them are localized in salt caverns (Mogilno and Kosakowo), constituting about $20 \%$ of total storage capacity. The remaining ones have been organized in depleted oil and gas fields. Apart from the storing capacity, another important factor which matters in this type of geoengineering objects is recovery capacity (possibility to quickly recover the medium). Underground Gas Storages organized in salt caverns are much more advantageous than their counterparts as far as the rate of recovery of the medium in a definite time is concerned [14].

Natural gas occupies the second position on the Polish energy list and its share is constantly increasing. The seasonal demand for this product, price oscillations and geopolitical situation necessitate the formation of energy reserves. Now the underground gas storages mean not only the market of strategic reserves, participation of Poland in the European gas market and competitiveness with other stock members but also better use of underground storage tanks as commercial buffers thanks to which Poland can count on the return of costs of erecting and maintaining these objects, and financial benefits in the future. Analogous to other European countries, Poland is obliged by EU energy legislation to introduce some changes in the existing law and issue respective legal acts regulating rhe underground storing of energy carriers in line with EU law. 
Table 1

Active capacity of underground gas storages in 2014 [2]

\begin{tabular}{|l|c|c|}
\hline \multicolumn{1}{|c|}{ UGS } & $\begin{array}{c}\text { Active capacity } 2014 \\
\left(\mathrm{mln} \mathrm{m}^{3}\right)\end{array}$ & $\begin{array}{c}\text { Max recovery capacity } \\
\left(\mathrm{mln} \mathrm{m}^{3} / \text { day }\right)\end{array}$ \\
\hline Brzeźnica & $65 / 100^{*}$ & 0.93 \\
\hline Husów & 500 & 5.76 \\
\hline Mogilno & $408 / 800^{*}$ & 18.00 \\
\hline Kosakowo & $119 / 250^{*}$ & 9.60 \\
\hline Strachocina & 360 & 3.36 \\
\hline Swarzów & 90 & 1.00 \\
\hline Wierzchowice & 1200 & 9.60 \\
\hline Daszewo & 30 & 0.38 \\
\hline Bonikowo & 200 & 2.40 \\
\hline Total & 2972 & \\
\hline
\end{tabular}

* Target storage capacity

The basic legal act on energy carriers, in that underground storing, is the Energy Law of 10 April 1997 (Official Journal of 1997 no. 54 item 348) with the most recent amendments of 2015. This law specifies obligations of entrepreneurs operating in the energy sector, focusing on the maintenance of equipment and installation in conditions allowing reliable and uninterrupted operation, providing deliveries to customers in line with the contracts and based on the equal treatment rule [12]. Another legal act on the capacity of obligatory energy reserves is the Law on reserves of oil, oil products and natural gas, and procedure in the case of hazarded fuel safety and disturbances on the oil market of 30 May 2014 (Official Journal of 2014 item 900). This law obliges companies dealing with these carriers and the State to create storage reserves, and defines the way of calculating the capacities [18]. This law implements the EU Council directive 2009/119/WE of 14 September 2009 imposing on the member countries the obligation of possessing minimum reserves of oil or oil products (EU Official Journal L 265 of 09.10.2009, p. 9). This act also details out procedures of creating and maintaining oil and natural gas reserves, specifies the place of storing in Poland and in member countries (on the basis of respective contracts and permits). The minimum reserve of natural gas corresponds to 30 days of average volume of import gas. Storages and the associated installations have to meet an additional condition, i.e. the medium should be returned to the system within maximum 40 days [1]. Through this act, Poland is also allowed to rent storage capacity to other EU member countries [4].

According to the Poland Energy Policy by the Year 2050 accepted by the Cabinet in 2015, Poland will increase its storing capacity for natural gas to provide the energy safety of the country (principal goal) through the development of underground gas storages of capacities guaranteeing uninterrupted deliveries, especially in crisis situations [11]. 
According to PGNiG data [2], at the end of 2015 Poland had over 90\% filled gas storages, and the stored carrier corresponded to a 54-day reserve. According to the regulations, Poland's Economy Minister should have at his disposal a gas reserve of (10.3 billion $\left.\mathrm{m}^{3} / 365 * 30\right) 0.85$ billion $\mathrm{m}^{3}$, to be recovered within 40 days, which corresponds to the daily recovery of $20-25 \mathrm{mln}^{3}$ [1]. Attention should be paid to the fact that only two of the nine gas storages were made in salt caverns, and that only from them the medium can be recuperated quickly. In the present system and with the existing technical potential of the storages, it will be difficult to create obligatory gas reserves for crisis situations and treat them as additional supplies for the transmission system. Similar values of maximum recovery capacities can be guaranteed only by UGS Mogilno and UGS Kosakowo, though their capacity does not cover the needs for strategic reserves. Bearing in mind the investment plan of PGNiG, reaching target storing capacities and maneuvering abilities for the strategic needs of the country, attention should be paid to storing home buffers in underground gas storage facilities in salt structures [19]. Logically, the existing storages should be developed and new ones built in well recognized salt structures to guarantee strategic capacities in each of them. They should not exceed 50\% of the cavern capacity. By doing so Poland could follow the lead of other countries and compromise the home interest of the country and make a commercial use of the storage facilities for the external contractors [17].

\section{PERSPECTIVE OF MAKING A NATURAL GAS STORAGE IN A SALT ROCK IN THE FORE-SUDETIC MONOCLINE}

The underground gas storage facilities in Poland have been localized both in depleted deposits (UGS Kosakowo) and in salt domes (UGS Mogilno). These structures differ in build which entails different design concepts.

The salt rock deposit in the Fore-Sudetic Monocline meets the criteria for a containerless storage facility of oil products $[14,15]$ :

- advantageous hydrogeological conditions typical of salt domes,

- advantageous geomechanical properties of salt rock (consolidated, impermeable, liable to strains) [6],

- advantageous leaching properties,

- relatively high thickness of deposit (where caverns of considerable volume can be made),

- insulation from aquifers,

- relatively small tectonic impact.

Scientists and practitioners specializing in the geomechanical stability of salt rock deposits in the aspect of using them for UGS show to the northwest area of the deposit, the Bytom Odrzański and Brzeg Głogowski area $[8,14,15]$ as a potential site for such an object. Rock layers from which the monocline has been built extend to WNW/ESE and NW/SE [3]. They gently dip at an angle of $2-5^{\circ}$ towards NE. Tectonic disturbances (graben, horsts, faults) can be found in the LGOM Permian, which vanish with the growing thickness of the Zechstein strata. Zechstein was formed in cyclothems Z1, Z2, Z3 and Z4. The oldest salt is represented by many types of halite (mainly medium crystalline). They can be intergrown 
with anhydrite and clayey substance, mainly at the bottom of the salt deposit. The basement of the salt deposit is made of Lower Anhydrite, Zechstein Limestone and Kupferschiefer underlain with Rotliegend sediments. The caprock is built of the Triassic, Tertiary and Quaternary sediments $[3,13]$.

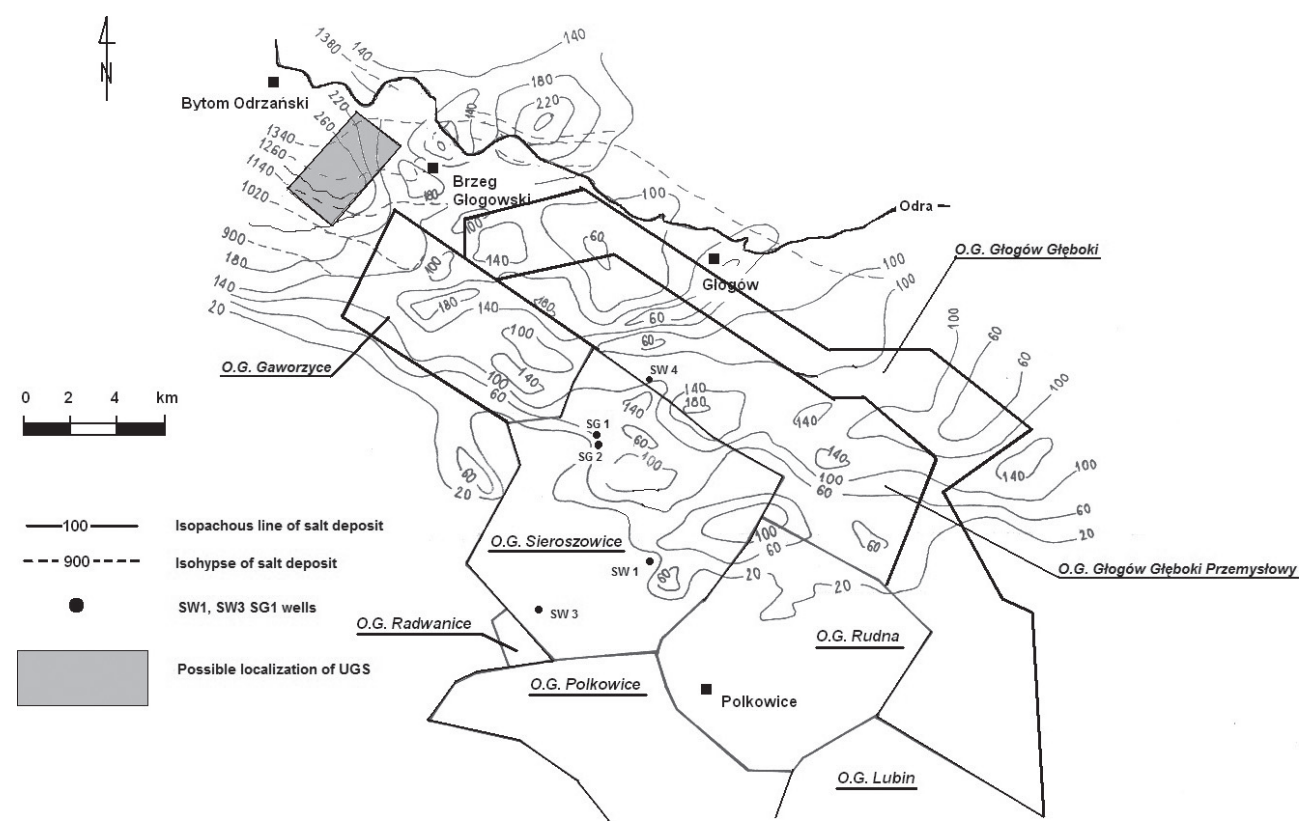

Fig. 1. Perspective localization of UGS in LGOM salt cavern based on $[3,13]$

The indicated area is localized in the northwest part of the Silesian Lowland (Fig. 1), on the left side of the Odra catchment area, running to the northeast at a distance of about $2 \mathrm{~km}$. The forest complex covers half of the discussed site, neighboring with the Nature 2000 area from the north. This area has been well recognized with geophysical surveys and drilling tests. It is probably cut with the Bytom Odrzański fault with about a $95 \mathrm{~m}$ throw. This is not an obstacle as far as UGS is concerned, if properly thick safety pillars are provided [16].

The basic problem relating to storing in UGS is the management of brine produced while building the storage and used during storage operation [16]. The brine cannot be discharged to the surface water courses (Oder river) because of environmental issues. Accordingly, the building of an UGS within the Fore-Sudetic Monocline will require solving the problem of brine management. It can be either sold to the existing industrial institutions (e.g. PCC Rokita) $[10]$ or discharged to the water-bearing layers.

The underground gas storage in a salt dome in the Fore-Sudetic Monocline would be the first such investment in the Lower Silesia region. Thus, the localization of the UGS in the indicated area would improve the natural gas supplies to the inhabitants of the Lower Silesia province. 


\section{ANALYSIS OF LABORATORY RESULTS OF SALT SAMPLES \\ FROM THE FORE-SUDETIC MONOCLINE - A BASIS FOR EVALUATION OF GEOMECHANICAL STABILITY OF UGS}

A cavern is defined as a space in a salt dome performed with engineering methods in the process of leaching, which is filled with an energy carrier (gas or liquid). Its basic task is providing an assumed storage regime with the maintained long-term stability and tightness of the object.

The concept of a storage facility has been oriented to the proper dimensioning of particular caverns and determining their distribution in the storing space. At this stage attention should be paid to the conditions of the salt rock deposition (depth of deposition and thickness of the dome) and properties of salt. The depth of deposition of the chamber has a significant influence on the minimum gas pressure in the chamber. The deeper the object is deposited, the more intense is the contraction of the rock mass and the faster is the convergence of the walls under the influence of rheological properties of the salt rock. The long-term stability of specific 'breathing' underground engineering objects will mainly depend on the intensity of the creep, which decides about the final stress-strain conditions of the rock medium as a construction material.

The geomechanical analysis of the assumed UGS model requires knowledge about the elasticity-plasticity-viscosity of the rock, which is the skeleton of the whole construction [7]. This is limited to defining strength parameters of the rock in the triaxial state of stress, solving the stability issue for the UGS, taking into account the rheological properties of the salt rock and applying suitable boundary conditions for determining long-term resistance of the rock. In practice the creep of the salt translates to a change of volume of the working. The contours of the old working will tend to move and slowly contract the storing cavern under the influence of changes inside the cavern (gas under varying pressure).

The geomechanical stability of caverns in the underground gas storage necessitates the absence of tensile stress in the roof of the chamber, sticking to the admissible values of reduced stresses and a proper distribution of storage caverns in the lattice, where the storing caverns are beyond the reach of the neighbors.

The analysis of the results of many years' experiments on salt from the Fore-Sudetic Monocline $[7,20]$ led to certain conclusions on the behavior of the material in the context of realization of underground constructions.

\section{Short-term analyses}

A typical strain-stress characteristic obtained in the process of conventional uniaxial compression has been presented in Figure 2. The analyses in a uniaxial state of stress were performed on cylindrical samples $h=120 \mathrm{~mm}$ and $d=60 \mathrm{~mm}$.

The basic stress-strain parameters could be defined on the basis of the such characteristics:

- longitudinal strain coefficient (elastic moduls): $E=1.75 \mathrm{GPa}$,

- transverse strain coefficient (Poisson's ratio): $v=0.27$,

- absolute dilatancy threshold, $\sigma_{D}=8.5 \mathrm{MPa}$,

- plasticity threshold, $\sigma_{P L}=16.3 \mathrm{MPa}$,

- angle of repose, $\rho=66.3^{\circ}$,

- coherence, $c=2.62 \mathrm{MPa}$. 


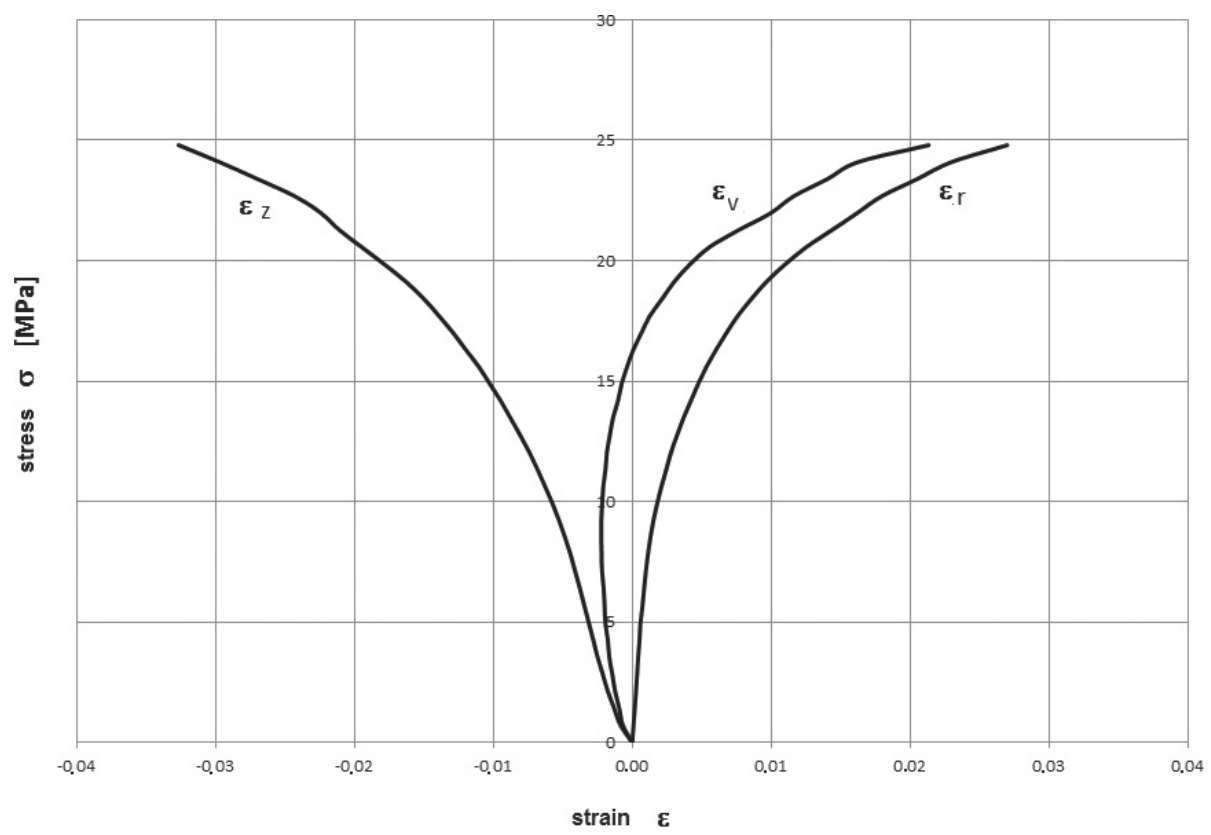

Fig. 2. Strain-stress characteristic of salt samples from Fore-Sudetic Monocline after classical uniaxial compressive tests

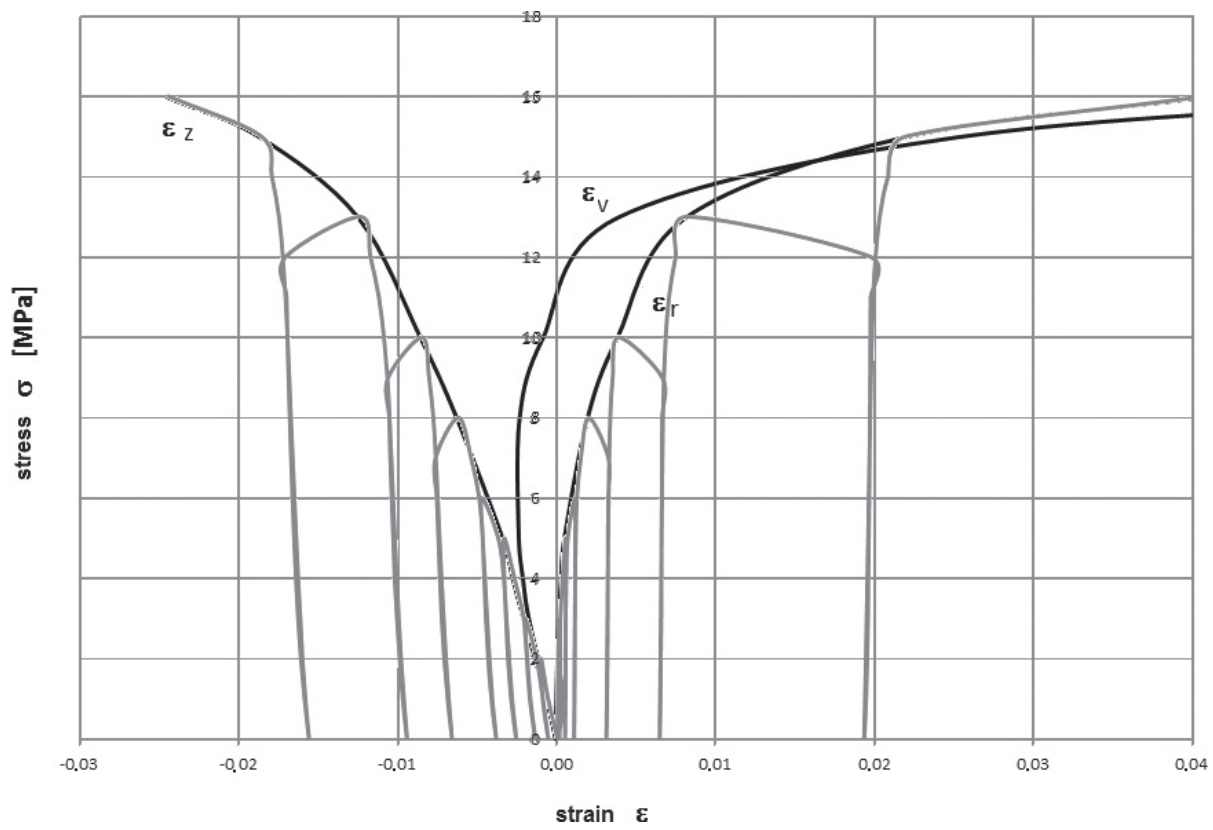

Fig. 3. Strain-stress characteristic of salt samples from Fore-Sudetic Monocline after cyclic uniaxial compressive tests 
Parameters of salt damaging in a uniaxial state of stress:

- compressive strength of salt, $R_{c}=24.81 \mathrm{MPa}$,

- tensile strength, $R_{r}=1.1 \mathrm{MPa}$.

Caverns are breathing, therefore cyclic compressive tests were performed and strains measured to define the qualitative changes of behavior of salt in the fatigue test. In Figures 2 and 3 we can see a difference in the resistance to compressive stress. The strength of salt in the fatigue test is about $65 \%$ of the compressive strength in a classic test. When the salt samples were subjected to varying loads, they had bigger radial and volumetric deformations than in the classic uniaxial compressive tests. Salt has a rheological memory and undergoes permanent deformations which increase with each stress cycle. Salt rock, being the environment of the cavern, undergoes similar processes. When the gas is injected to the cavern and the pressure increases there, the pressure exerted by gas on the contour of the working will try to outbalance the rock mass pressure. This situation is favorable, provided all safety measures are maintained and the inner pressure is not exceeded. The second extreme case is when the gas is pumped out of the storage and the pressure decreases in the cavern. The pressure in the cavern cannot drop below the minimum level so that the stress criterion is not exceeded and tensile stress (particularly dangerous in the roof of the chamber) appears.

The strain-stress characteristic for salt from the planned localization is non-linear and can be approximated [4] over the whole range of stress with the equation:

$$
\varepsilon=\frac{\sigma}{E}+k\left(\frac{\sigma}{E}\right)^{n}
$$

where $E, k, n$ - figure parameters, found through the approximation of the experimental curve. Parameter E corresponds with the elasticity coefficient, which represents reversible strain in the cyclic compressive test at the stage of loading; $k$ and $n$ are responsible for permanent deformations in the total deformation and are equal to:

$$
\begin{aligned}
& E=1.94 \mathrm{GPa} \\
& k=1401.45 \\
& n=0.61
\end{aligned}
$$

In the triaxial compressive tests, performed on cylindrical samples $84 \mathrm{~mm}$ high and $42 \mathrm{~mm}$ of diameter, the strength conditions characterizing the behavior of rock in similar-to-real conditions were determined at 6 levels of radial pressure $\left(\sigma_{3}=5-30 \mathrm{MPa}\right)$ (Fig. 4). Despite various types of behavior of the samples (two salt classes: brittle and ductible), the authors managed to define the parameters defining the behavior of salt in a complex state of stress.

The analysis of the test results revealed that salt has a strong nonlinear tendency and undergoes absolute dilatancy at an early stage of loading. Salt characterized by low strength and brittleness was the ascribed Coulomb-Mohr strength condition and the respective constants were defined: coherence $c=6.4 \mathrm{MPa}$ and angle of repose $\rho=15^{\circ}$. For a ductible salt the angle of repose corresponded to various stages of cataclastic flow above the plasticity threshold. These values were low, on average about $\rho=4^{\circ}[7]$. 
Bearing in mind the possible mining activity and considerable depth of deposition of salt, the behavior of salt was described (Fig. 5) in a triaxial state of stress with the G. Yin strength condition:

$$
K_{2}=a+b I_{1} \sqrt[3]{K_{3}}
$$

where:

$$
\begin{aligned}
K_{2} & =0.5\left(\sigma_{1^{2}}+\sigma_{2^{2}}+\sigma_{3^{2}}\right) \text { and } K_{3}=0.5\left(\sigma_{1^{3}}+\sigma_{2^{3}}+\sigma_{3^{3}}\right) \\
I_{1} & - \text { first stress invariant, } \\
a, b & - \text { parameters of equation from triaxial compressive test. }
\end{aligned}
$$

The parameters of the equation defined at a correlation coefficient of 0.98 equal to $a=207.91 \mathrm{MPa}^{2}$ and $b=0.42$ and do not differ from literature data [5].

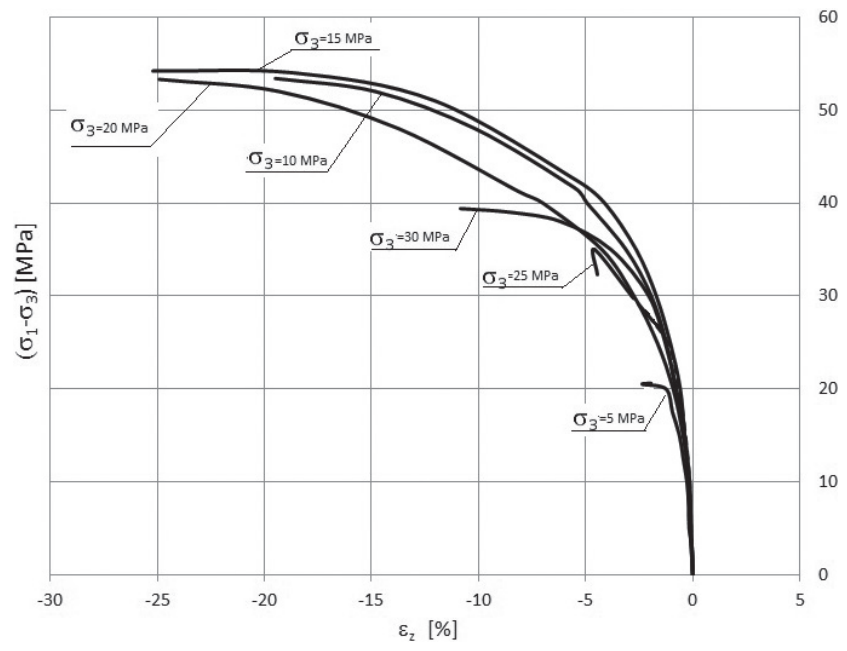

Fig. 4. Strain-stress characteristic $\left(\sigma_{1}-\sigma_{3}\right)=f\left(\varepsilon_{z}\right)$ of salt samples from Fore-Sudetic Monocline after triaxial compressive tests

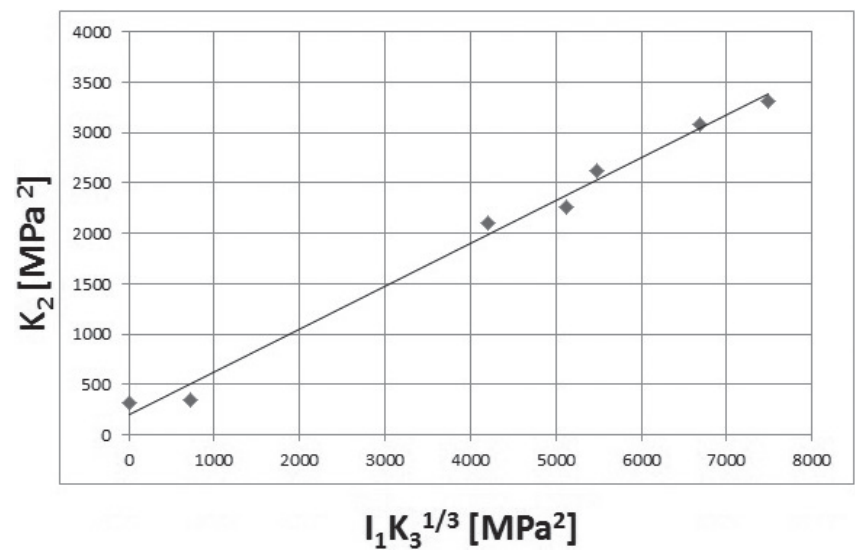

Fig. 5. Approximation of G. Yin strength condition for salt rock from Fore-Sudetic Monocline 


\section{Long-term rheological analyses}

The salt rock creep decides about the final strain-stress condition of the salt rock. Classic creep (frequently referred to in literature $[7,9,20]$ ) consists of three phases: primary, stationary and final. Without going into details, phase 2 and 3 usually are observed at higher loads; phase 2 can also appear at relatively low loads but maintained over a long time horizon. A number of creep tests at various stress level were performed on cylindrical salt samples $84 \mathrm{~mm}$ high and $42 \mathrm{~mm}$ of diameter from O.G. Sieroszowice [20] (Fig. 6). Only in low load conditions the salt remained at the creep phase 1 , at $\sigma_{0} \geq 16 \mathrm{MPa}$ the samples quickly entered phases 2 and 3 and were damaged. The stress level $\sigma_{0} \geq 16 \mathrm{MPa}$ ) over which the samples were damaged corresponded to the yield point of salt in the uniaxial compressive test. The samples were damaged at $\sigma_{0} \geq 0.6 R_{c}$ corresponding to the long-term resistance to compressive tests in a uniaxial stress condition.

The experimental curves at five stress levels corresponding to $(0.1-0.9) R_{c}$ for salt rock have been presented in Figure 6.

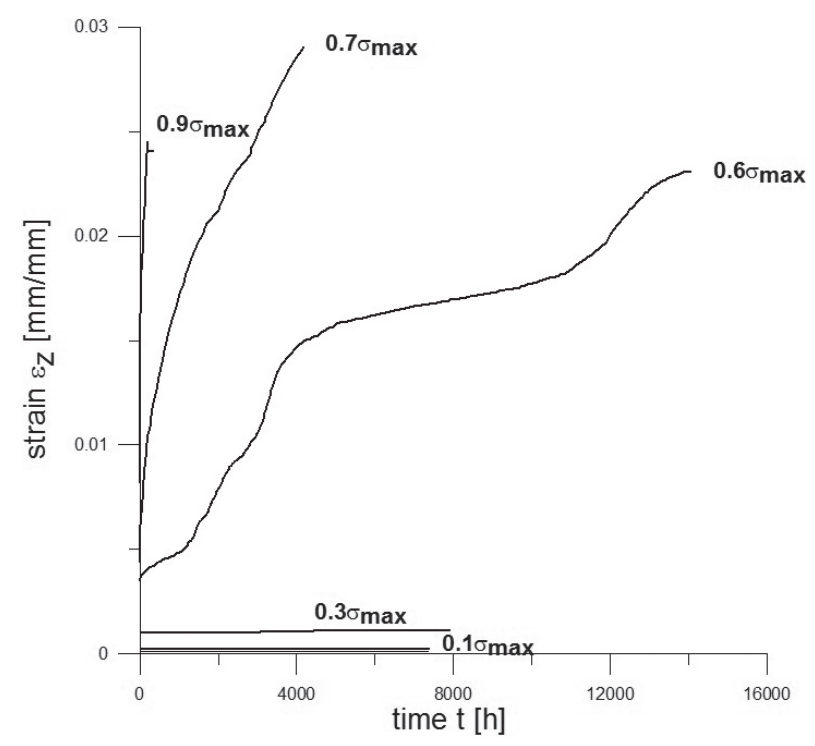

Fig. 6. Experimental creep curves $\varepsilon_{\mathrm{z}}=f(t)$ of salt samples in a uniaxial state of stress

As a result of the approximation of the creep curves (Fig. 7a, b, c) with the power creep law for samples tested in constant stress conditions $(0.6-0.9) R_{c}$ material creep constants were determined (Tab. 2). The tests were performed in constant humidity and temperature conditions.

The uniaxial creep strain was described with the power creep law in the form:

$$
\varepsilon=\varepsilon_{0}+B \sigma^{n} t^{m}
$$

where:

$n, m$ - material constants,

$B-$ creep liability at a given temperature $T=293 \mathrm{~K}$. 
a)

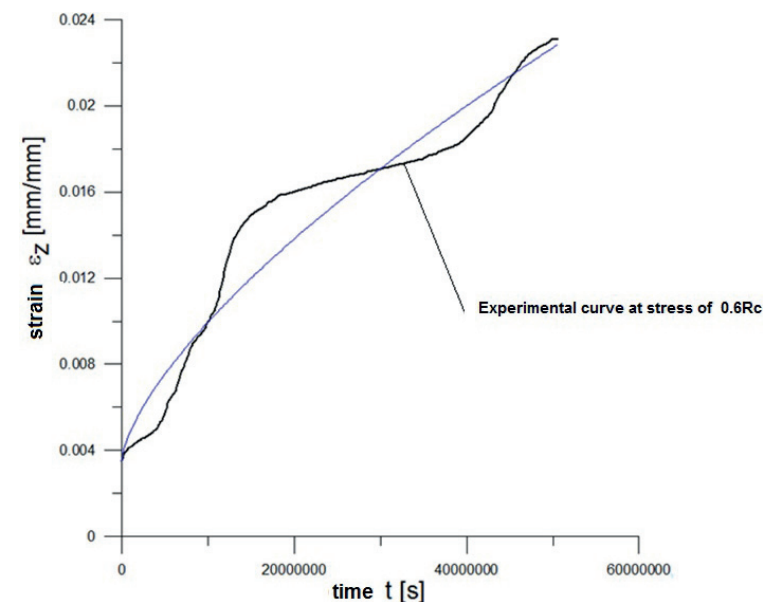

b)

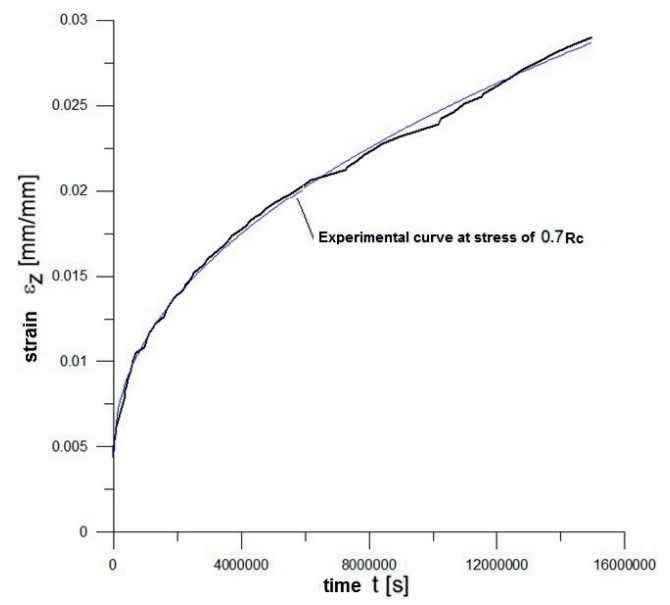

c)

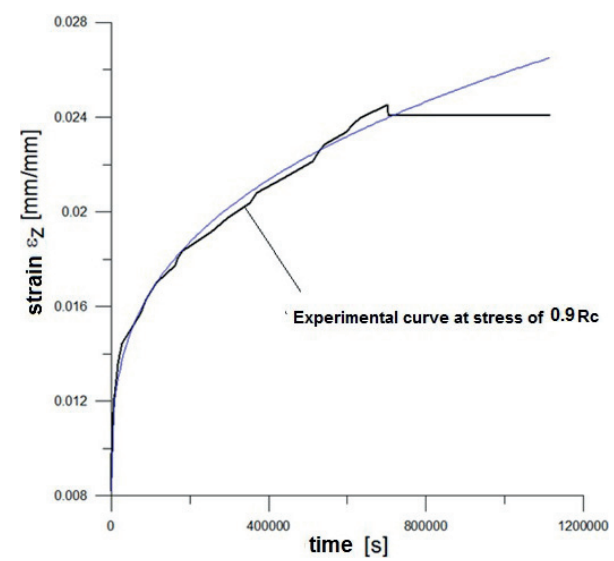

Fig. 7. Approximations of experimental creep curves $\varepsilon_{z}=f(t)$ of salt samples with power creep law at stress: a) $0.6 R_{c}$; b) $0.7 R_{c}$; c) $0.9 R_{c}$ 
Table 2

Material constants for analyzed salt, approximated with power model (3)

\begin{tabular}{|c|c|c|c|c|}
\hline$\sigma_{0} / R_{c}$ & $B\left[\mathrm{~Pa}^{-\mathrm{n}} \cdot \mathrm{s}^{-\mathrm{m}}\right]$ & $n[-]$ & $m[-]$ & $\begin{array}{l}\text { Correlation } \\
\text { coefficient }\end{array}$ \\
\hline 0.6 & $4.025 \cdot 10^{-15}$ & \multirow{3}{*}{1.03} & 0.68 & 0.95 \\
\hline 0.7 & $3.182 \cdot 10^{-13}$ & & 0.47 & 0.99 \\
\hline 0.9 & $5.512 \cdot 10^{-12}$ & & 0.32 & 0.99 \\
\hline
\end{tabular}

\section{CONCLUDING REMARKS}

The prediction of behavior of the salt rock should be based on such very important elements as knowledge of geomechanical properties of rocks and observations in situ. They create the bases for design works and analyses of stability of underground geoengineering objects, i.e. storing caverns.

The analysis of the fuel market, legal acts and the energy safety premises show that underground gas storages in Poland are a preferable development option.

An area in a salt deposit in the Fore-Sudetic Monocline was found to meet the requirements of a planned UGS, where a series of laboratory tests was performed. Parameters of salt damage as well as strain-stress parameters were determined during short-term tests in uniaxial and triaxial state of stress. The analyzed salt turned out to behave nonlinearily. In the triaxial tests the salt samples were either brittle or ductile. This could be caused by the presence of microcracks in the cores generated at an early stage of sampling, which in turn had an effect on the material from which the laboratory samples were prepared.

Research teams from various scientific centers in Poland conduct intensive in situ laboratory experiments on salt material to recognize its properties. The obtained results have not only cognitive value but also create a bases for designing practical solutions in mining, underground construction and geoengineering. It would be an interesting idea to collect all results of experiments conducted in scientific centers in Poland (i.e. AGH-UST, Warsaw University of Technology, Silesian Technical University, CUPRUM CBR, OBRGSCH CHEMKOP, ITG KOMAG, etc.) and create a reference database, which would give a broader view on the behavior of salt material. Particularly valuable are the results of long-term experiments on rheological properties of salt as an elastic-viscous medium.

The future research works should be focused on a broader analysis of the results of long-term creep tests inspired by the behavior of the gas cavern in the extreme pressure regime conditions [20]. The comparison of results of samples subjected to a conventional uniaxial creep test and cyclic tests will be addressed in further publications.

\section{REFERENCES}

[1] Brzeziński T., Wawrzynowicz A.: Rozwój segmentu magazynowania paliw gazowych, zmiany otoczenia prawnego, zasady funkcjonowania oraz znaczenie segmentu dla ryn$k u$. Rynek Energii, nr 5 (114), 2014, pp. 3-15. 
[2] http://gk.pgnig.pl/documents/10184/1007990/PGNiG_WL2014_POL_w5_druk.pdf/ 646853d6-3ae0-4607-8e2b-8dbafbe02ce8 [Access 06.03.2017].

[3] Dokumentacja geologiczna soli kamiennej występującej ponad złożem rud miedzi kopalni ,,Sieroszowice” (Zasoby w kat. C1 i szacunkowe), red. M. Preidl, Kraków 1990.

[4] Dyrektywa Rady 2009/119/WE z dnia 14 września 2009 r. nakładajaca na państwa członkowskie obowiązek utrzymywania minimalnych zapasów ropy naftowej lub produktów ropopochodnych. Dz.Urz. UE L265/9 z 09.10.2009, p. 9.

[5] Flisiak D.: Laboratoryjne badania właściwości geomechanicznych soli kamiennej z wybranych złóż cechsztyńskich. Gospodarka Surowcami Mineralnymi, t. 24, z. 3/2, 2008.

[6] Kłeczek Z., Radomski A., Zeljaś D.: Podziemne magazynowanie. Prace naukowe Monografie CMG KOMAG, Gliwice 2005.

[7] Kłeczek Z., Zeljaś D.: Naukowe podstawy i praktyczne zasady budowy w Polsce podziemnego składowiska odpadów niebezpiecznych. Instytut Techniki Górniczej KOMAG, Gliwice 2012.

[8] Kłeczek Z.: Wytężenie górotworu solnego wokót podziemnych kawernowych magazynów gazu. Wydawnictwo Centrum Badawczo-Projektowe Miedzi „Cuprum”, Wrocław 1999.

[9] Kunstman A., Poborska-Młynarska K., Urbańczyk K.: Zarys otworowego ługownictwa solnego. Aktualne kierunki rozwoju. Uczelniane Wydawnictwa Naukowo-Dydaktyczne AGH, Kraków 2002.

[10] Maciejewski A.: Podziemne magazynowanie paliw płynnych. Gospodarka Surowcami Mineralnymi, t. 24, z. 3/2, 2008, pp. 39-55.

[11] Polityka energetyczna Polski do 2050 roku. Ministerstwo Gospodarki, Warszawa 2015.

[12] Ustawa z dnia 10 kwietnia 1997 roku - Prawo energetyczne. Dz.U. 1997, nr 54, poz. 348.

[13] Szybist A.: Złoże solne w Lubińsko-Głogowskim Okręgu Miedziowym oraz geologiczne-górnicze warunki jego udostępnienia. Archiwum Zakładu Złóż Soli i Surowców Chemicznych AGH w Krakowie, 1978 [typescript].

[14] Ślizowski J., Lankof L., Wojtuszewska K.: Geomechaniczna ocena optymalnej głębokości komór magazynowych gazu ziemnego w polskich złożach soli kamiennej. WUG: Bezpieczeństwo Pracy i Ochrona Środowiska w Górnictwie, nr 6(154), 2007, pp. 50-51.

[15] Ślizowski J., Serbin K., Wiśniewska M.: Efektywna pojemność komór magazynowych gazu w pokładowych złożach soli kamiennej. Geologia, t. 36, z. 2, 2010, pp. 407-417.

[16] Ślizowski J. Urbańczyk K., Lankof L., Serbin K.: Analiza zmienności polskich pokładów soli kamiennej w aspekcie magazynowania gazu. Wiertnictwo, Nafta, Gaz, t. 28, z. 1-2, 2011, pp. 431-443.

[17] Trubalska J.: Podziemne magazyny gazu jako element bezpieczeństwa energetycznego Polski. Teka Kom. Politol. Stos. Międzynar. - OL PAN, nr 9, 2014, pp. 33-50.

[18] Ustawa z dnia 30 maja 2014 roku o zapasach ropy naftowej, produktów naftowych i gazu ziemnego oraz zasadach postępowania w sytuacjach zagrożenia bezpieczeństwa paliwowego państwa i zakłóceń na rynku naftowym, Dz.U. 2014, poz. 900.

[19] Zawisza A.: KPMG w Polsce w perspektywie roku 2015 oraz 2020. Geologia, t. 37, z. 2, 2011, pp. 293-306.

[20] Zeljaś D.: Ocena geotechnicznych możliwości podziemnego składowania odpadów niebezpiecznych w złożu soli kamiennej LGOM. Doctoral thesis, Kraków 2008. 